\title{
Clinical evaluation of enalapril maleate and furosemide usage in dogs with degenerative myxomatous mitral valve, chf functional class $\mathbf{~ I b}^{1}$
}

\author{
Rodrigo P. Franco ${ }^{2 *}$, Gener T. Pereira ${ }^{3}$ and Aparecido A. Camacho ${ }^{4}$
}

\begin{abstract}
Franco R.P., Pereira G.T. \& Camacho A.A. 2011. Clinical evaluation of enalapril maleate and furosemide usage in dogs with degenerative myxomatous mitral valve, chf functional class Ib. Pesquisa Veterinária Brasileira 31(9):791-797. Departamento de Clínica Médica e Cirúrgica de Pequenos Animais, Faculdade de Ciências Agrárias e Veterinária, Universidade do Estado de São Paulo, Via de Acesso Prof. Paulo Donato Castellane s/n, Jaboticabal, SP 14884-900, Brazil. E-mail: vetrpf@yahoo.com.br

Degenerative myxomatous mitral valve (DMMV) is a heart disease of high incidence in small animal clinical medicine, affecting mainly older dogs and small breeds. Thus, a scientific investigation was performed in order to evaluate the clinical use of the medicines furosemide and enalapril maleate in dogs with this disease in CHF functional class Ib before and after the treatment was established. For this purpose 16 dogs with the given valve disease were used, separated into two groups: the first received furosemide $(\mathrm{n}=8)$ and the second received enalapril maleate $(\mathrm{n}=8)$ throughout 56 days. The dogs were evaluated in four stages (T0, T14, T28 and T56 day) in relation to clinical signs, hematological, biochemical and serum assessment, which included serum angiotensin converting enzyme (ACE) and aldosterone, as well as radiography, electrocardiography, Doppler-echocardiography and blood pressure. The results regarding the clinical, hematological and serum chemistry evaluations revealed no significant changes in both groups, but significant reductions in the values of ACE and aldosterone in the group receiving enalapril maleate were verified. The radiographic examination revealed reductions of VHS values and variable Pms wave of the electrocardiogram in both groups, but no changes in blood pressure values were identified. The echocardiogram showed a significant decrease of the variables LVDd/ $s$ in the studied groups and the FS\% in animals that received only enalapril. Therefore, analysis of results showed that monotherapy based on enalapril maleate showed better efficiency of symptoms control in patients with CHF functional class Ib.
\end{abstract}

INDEX TERMS: Myxomatous degeneration, mitral valve, dogs, cardiology.

RESUMO.- [Avaliação clínica da utilização do maleato de enalapril e furosemida em cães com doença degenerativa mixomatosa da válvula mitral, classe funcional Ib.] A doença degenerativa mixomatosa da válvula mitral (DDMVM) é uma cardiopatia de alta incidência na clínica médica de pequenos animais, acometendo mormente cães idosos e raças de pequeno porte. Desta forma, foi realizada uma investigação científica objetivando avaliar clinicamente a utilização

\footnotetext{
${ }^{1}$ Received on August 28, 2010.

Accepted for publication on March 13, 2011.

${ }^{2}$ Departamento de Clínica Médica e Cirúrgica de Pequenos Animais, Faculdade de Ciências Agrárias e Veterinária (FCAV), Universidade do Estado de São Paulo (Unesp), Via de Acesso Prof. Paulo Donato Castellane s/n, Jaboticabal, SP 14884-900, Brazil. *Corresponding author: vetrpf@yahoo.com.br

${ }^{3}$ Departamento de Ciências Exatas, FCAV-Unesp, Jaboticabal, SP.

${ }^{4}$ Departamento de Clínica Médica e Cirúrgica de Pequenos Animais, FCAVUnesp, Jaboticabal, SP.
}

dos fármacos maleato de enalapril e furosemida em cães com a referida enfermidade na classe funcional Ib da ICC, antes e após a terapêutica implantada. Para isso, utilizaram-se 16 cães portadores da valvulopatia supracitada, distribuídos em dois grupos; com o primeiro recebendo furosemida $(n=8)$ e o segundo maleato de enalapril $(\mathrm{n}=8)$, durante 56 dias. Os cães foram avaliados em quatro momentos (T0, T14, T28 e T56 dias) quanto aos sinais clínicos e parâmetros hematológicos e bioquímico-séricos, que incluíram concentrações séricas da enzima conversora da angiotensina (ECA) e aldosterona, como também avaliações radiográficas, eletrocardiográficas, ecodopplercardiográficas e da pressão arterial. Os resultados quanto aos parâmetros clínicos, avaliações hematológicas e bioquímicas séricas não revelaram alterações significativas em ambos os grupos, mas reduções significativas nos valores de ECA e aldosterona no grupo que recebeu o maleato de enalapril foram identificadas. Ao exame radiográfico obser- 
vou-se reduções nos valores de VHS e na variável onda Pms do eletrocardiograma em ambos os grupos, mas sem alterações nos valores da pressão arterial. Por sua vez, o ecodopplercardiograma evidenciou diminuição significativa das variáveis DIVEd/s nos grupos estudados e na FEC\% nos cães que receberam somente enalapril. Portanto, a análise dos resultados encontrados indicou que a monoterapia fundamentada no maleato de enalapril apresentou melhor eficiência no controle do quadro clínico em pacientes da classe funcional Ib da ICC.

TERMOS DE INDEXAÇÃO: Degeneração mixomatosa, válvula mitral, caninos, cardiologia.

\section{INTRODUCTION}

The mitral valve's chronic fibrosis, also known as degenerative myxomatous mitral valve (DMMV), has a predisposition to affect older dogs and small breeds (O'Grady 1997), characterized by normal valvular architecture loss due to increasing fundamental substance with no inflammatory reaction tissue replacement by fibrous myxomatous tissue (Jeresaty 1974, Mucha 2007). Its etiology is still unknown, although different mechanisms may be involved, such as genetics, thoracic trauma, bacterial endocarditis and valve prolapse (Swenson et al. 1996, Perdersen 2000). Epidemiological studies have identified incidences above $60 \%$ in canine population of patients with heart disease, depending on the criteria and diagnostic method used (Detweiler \& Patterson 1965).

With the heart disease's clinical evolution, there is a decrease in cardiac output by activating compensatory mechanisms, such as the renin angiotensin aldosterone system (RAAS) and sympathetic nervous system (Snyder 1991, Knight 1992). These mechanisms lead to the development of chronic clinical signs of congestive heart failure (CHF) (Calvert 1991, Roth 1993, Camacho 1996, De Morais 2000).

The diagnosis is based on physical examination and laboratory tests, with emphasis on cardiac evaluation. The patient presents holosystolic murmur audible in mitral valve focus with the sound intensity varying with the degree of valve insufficiency (Kittleson 2006). In relation to radiography, Soares et al. (2004) evaluated the radiographic features of chronic valve disease in dogs with a murmur of low to moderate intensity, describing that only $25 \%$ of the evaluated animals had cardiectasia. In relation to echocardiography, Firm \& Petric (2002) conducted a retrospective epidemiological study in 195 dogs with DMMV, scoring the ratio LA/Ao with the functional classes of CHF, showing in their results that the animals had functional class Ib blow systolic mitral grade III to IV/VI and LA/Ao ratio between $1.92 \mathrm{~cm}$. In the same year, Domenech et al. studied other echocardiographic prognostic indicators in 704 dogs with mitral valve insufficiency, using the variables LVD, IVS and mean LA/Ao, according to the International Small Animal Cardiac Health Council (ISACHC) classification. Both studies previously mentioned have reported that the Doppler echocardiographic variables can be used as a prognostic indicator of the heart disease in question.

In 1998, Biller et al reported that dogs with DMMV treated with enalapril maleate for six months presented reductions in $\mathrm{FS} \%$ and left ventricular internal diameter in diastole (LVDd) leading to improvement of syncope and pulmonary congestion. Atkins et al. (2002) have further highlighted its effectiveness after two years of therapy, reporting the absence of laboratory abnormalities in treated patients.

Among other medicines used in dogs with CHF, furosemide, a loop diuretic, promotes the increase in the excretion of sodium and chloride ions in the distal renal tubule, leading to fast diuresis and decreased preload (Jackson 1996). It is considered the diuretic of choice for patients with fluid retention secondary to CHF with the recommended therapeutic dosage of 2 to $4 \mathrm{mg} / \mathrm{kg}$ every 12 or 24 hours, and may vary depending on the severity of clinical signs and concomitant medications used (Pereira 1996, Keene \& Rush 1997, Kogica 1999).

Once the DMMV is a major cardiovascular disease in veterinary medicine (Mucha 2007), we aimed to investigate which emphatically pharmacological therapy would provide benefit to survival of dogs with the valve disease in CHF functional class Ib, using enalapril maleate or furosemide. The evaluations were based on clinical aspects, laboratory features, radiography, electrocardiography, echocardiography and blood pressure added of serum values of angiotensin converting enzyme and aldosterone before and after application of studied therapeutic protocols.

\section{MATERIALS AND METHODS}

Sixteen dogs with DMMV CHF functional class Ib naturally acquired were used, characterized by asymptomatic cardiomegaly. The diagnosis of the animals was based on the review, suggestive clinical history and physical examination, and serum biochemical and hematological evaluation, electrocardiography, radiography, echocardiography and blood pressure. Dogs with gastrointestinal dysfunction were excluded, in order to avoid interference on the absorption of the medicines to be evaluated.

The inclusions of patients in different treatment protocols were previously established, according to their order of arrival in the clinical service. Thus, the animals were randomly separated into two groups described below:

G1: composed of eight dogs with CHF functional class Ib, treated with oral furosemide at a dosage of $2 \mathrm{mg} / \mathrm{kg}$ once a day.

G2: composed of eight dogs with CHF functional class Ib, treated with enalapril maleate oral dose of $0.5 \mathrm{mg} / \mathrm{kg}$ once daily.

Thus, each animal was clinically assessed four times over a total period of 56 days, including the first visit (T0) and after therapy was instituted (T14, T28 and T56 days). The owners were required to provide a feed with low sodium content as the dietary habits of patients.

Physical examinations were performed by the same person, along with the classification of the degree of mitral valve regurgitation after cardiac auscultation. If any animal presented severe decompensation, resulting in imminent risk of death, it would be treated properly and subsequently excluded from the study.

Hematologic, serum and biochemical evaluations, as well as the

\footnotetext{
${ }^{5}$ Acquisition module for the electrocardiogram ECG-PC computer model, Teb Tecnologia Eletrônica Brasileira Ltda, Av. Diederichsen 1057, São Paulo, SP, Brazil.

${ }^{6}$ DX 2710 - Dixtal, Av. Torquato Tapajós 2.236 (Prédios A1 e A2), Manaus, AM, Brazil.

${ }^{7}$ 300S Pandion Vet - Pie Medical Equipment, Philipsweg 1, 6227 AJ Maastricht, Holanda.
} 
concentrations of alanine aminotransferase (ALT), alkaline phosphatase (ALK PHOS), urea, creatinine, total protein (PPT), albumin, sodium and potassium (Keene \& Rush 1997) were performed at first visit and 56 days after the treatment, along with the measurement of serum ACE and aldosterone. Serum levels of aldosterone were obtained by radioimmunoassay in duplicate, while the values of ACE obtained by simplified enzymatic method previously developed for trials of ACE in human blood serum (Silva 2006).

In order to institute the final diagnosis, radiographs obtained in right lateral and dorsal-ventral recumbent were conducted, trying to observe the cardiectasia, when the sum of VHS was superior to 10.5 vertebral bodies (Buchaman \& Bucheler 1995). At the electrocardiogram ${ }^{5}$ was used a computerized device, which allows the simultaneous acquisition of six leads (DI, DII, DIII, aVL, aVF and aVR), speed $50 \mathrm{~mm}$ / second, calibrated to one centimeter equals $1 \mathrm{mV}$, allowing to obtain the electrocardiographic tracing and subsequent interpretation (Tilley 1992, Wolf et al. 2000).

In relation to systolic, diastolic and mean blood pressure, these were obtained by non-invasive method using an oscillometric ${ }^{6}$ device. In echodoppler cardiogram ${ }^{7}$, echocardiographic variables were analyzed through the $\mathrm{M}$ - mode: internal diameter of the right ventricle (RVDI), left ventricular internal diameter (LVDI), interventricular septum thickness (IVS) and thickness of the left ventricular free wall (LVPWD), all of these variables were recorded at diastole (d) and systole (s) end. Also, the fractional thickening of the interventricular septum (IVS\%) and left ventricular free wall (LVPW\%), ejection (EF\%) and shortening fractions(FS\%), the aortic diameter (Ao) and left atrial (LA), and the ratio LA / Ao were verified. In the evaluation of Doppler transmitral flow, we measured the peak velocity of left ventricular filling fast (PEV), slow (PAV) and the relationship between them. After directing the line-cursor through the mitral valve, the time velocity integral (FVI) of mitral regurgitant flow was measured using continuous Doppler, together with the velocity of mitral valve regurgitation (Boon 1998).

The data obtained in this study were statistically analyzed comparing the changes in the four assessments between the G1 and G2, by analysis of variance with repeated measures on one factor group and time. The statistical method used to evaluate the significant variables and the comparison two by two, was the Tukey test with $\mathrm{p}$ value $<0.05$ was considered significant.

\section{RESULTS}

Clinical variables such as color of mucous membranes, femoral pulse, heart rate and respiratory rate, rectal temperature and body weight were measured in all assessments during the study, which showed no statistical variation between groups. Regarding age, it became evident the incidence of animals with CHF functional class Ib, between 8 and 11 years old, characterized by small breed dogs, with racial predisposition for Poodle (50\%), Pinscher (20\%), Dachshund (12\%) and mixed breed (18\%), weighing from two to seven kilograms.

During anamnesis, the owners reported the absence of CHF clinical signs, but clinical signs of mild cough were reported in $20 \%$ of the animals. On physical examination, mitral systolic murmur grade III or IV/VI was identified in all animals.

The hematological and serum-biochemical evaluations were performed at baseline (T0) and at the end of the studied period (day T56), showing no significant changes. Though, in group G1, a non-significant increase of hematocrit (Hct),

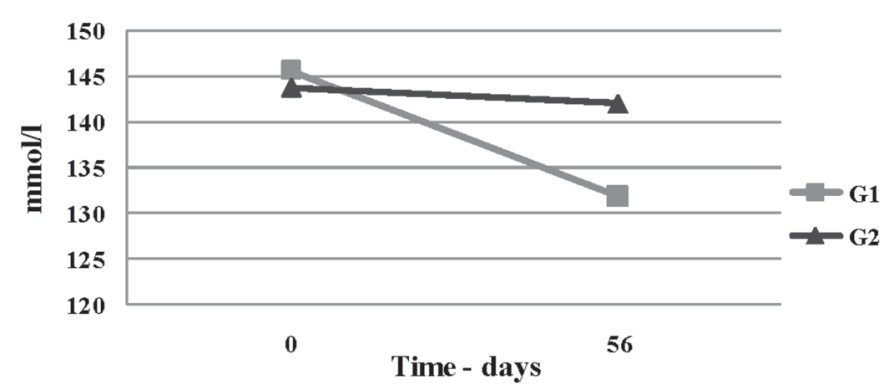

Fig.1. Graphical representation of averages relating to serum levels of sodium in dogs with DDMVM functional class Ib before and after administration of therapies.

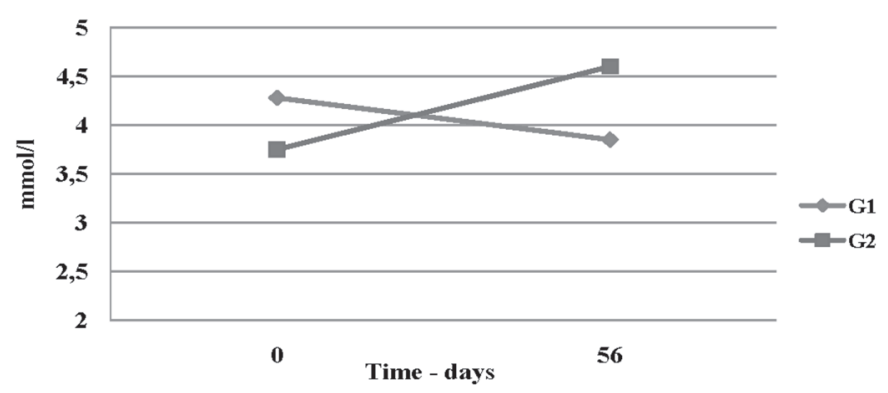

Fig.2. Graphical representation of averages relating to serum potassium of dogs with DDMVM functional class Ib before and after administration of therapies.

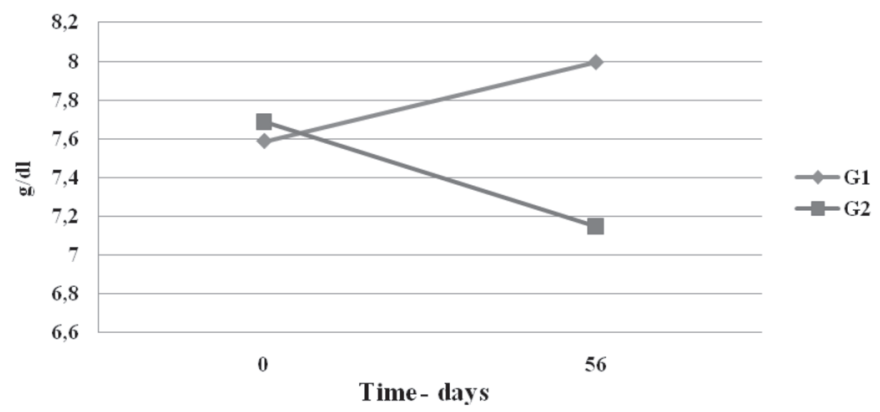

Fig.3. Graphical representation of averages relating to serum levels of total plasma proteins of dogs with DDMVM functional class Ib before and after administration of therapy.

erythrocytes (He), hemoglobin ( $\mathrm{Hb}$ ) and plasma total protein (PTP) (Fig.1), after the establishment of therapy with furosemide, was observed. In serum-biochemical assay both groups showed no significant changes. However, there was a trend toward a reduction in urea, creatinine, alanine aminotransferase (ALT) and alkaline phosphatase (ALK. PHOS.) and sodium ( $\mathrm{Na}$ ) in both groups (Fig.2). Moreover, the serum values of potassium $(\mathrm{K})$ showed a reduction in $\mathrm{G} 1$, with a slight increase in G2, but both were not significant (Fig.3).

The serum concentrations of ACE were not altered significantly between groups, indicating similarity between them. Although, it became significant $(p<0.01)$ at the end of the assessment, in G2, which received enalapril maleate, when compared with group G1, that received furosemide. Serum levels of aldosterone demonstrated reduction in both groups throughout the assessment, though significant $(\mathrm{p}<0.01)$ only in group G2 (Table 1).

Blood pressure was measured in all animals and no sig- 
Table 1. Mean and variance analysis of ACE and aldosterone concentrations obtained in groups of dogs affected by DMMV with CHF functional class Ib $(n=8)$ in two different stages of evaluation, according to therapeutic protocols previously determined

\begin{tabular}{|c|c|c|c|c|c|c|c|}
\hline \multirow[t]{3}{*}{ Variable } & \multicolumn{6}{|c|}{ ACE and aldosterona concentrations } & \multirow[t]{3}{*}{ References } \\
\hline & \multicolumn{2}{|c|}{$\mathrm{G} 1(\mathrm{n}=8)$} & \multicolumn{2}{|c|}{ G2 $(n=8)$} & & \\
\hline & T0 & T56 & T0 & T56 & Group & Time & \\
\hline $\mathrm{ACE} *(\mathrm{U} / \mathrm{L})$ & $281.3+/-51.71$ Аа & $224.8+/-55.74^{\mathrm{Aa}}$ & $265.9+/-67.14$ Аа & $142.1+/-36.73^{\mathrm{Ba}}$ & 0.14 & $0.0001^{+}$ & $239-299$ \\
\hline $\begin{array}{l}\text { Aldosterone** } \\
(\mathrm{pg} / \mathrm{mL})\end{array}$ & $50.45+/-67.32 \mathrm{Aa}$ & $45.47+/-34.72^{\mathrm{Aa}}$ & $69.1+/-33.48$ Аа & $34.59+/-36.09^{\mathrm{Ba}}$ & 0.916 & $0.0003^{+}$ & $5-345$ \\
\hline \multicolumn{8}{|c|}{$\begin{array}{l}{ }^{*} \text { P }<0.05=\text { significant difference at } 5 \%,+P<0.01=\text { Significant difference at } 1 \% \text {. }{ }^{\text {A }} \text { Means followed by the same uppercase letter do not differ by } \\
\text { Tukey test, analyze variance in Time; a means followed by same letter do not differ by Tukey test, variance analysis in the Group. } \\
\text { References: }{ }^{*} \text { B.E.T. Laboratories, Endocrinologia Veterinária (Michigan States University, University of California, Davis.); }{ }^{* *} \text { Silva R.R. 2006. De- } \\
\text { terminação da atividade sérica da enzima conversora da angiotensina por método enzimático simplificado: valores de referência para cães sadios } \\
\text { e avaliação em insuficientes renais crônicos. Tese de Doutorado, Faculdade de Ciências Agrárias e Veterinárias, Universidade Estadual Paulista } \\
\text { (Unesp). Jaboticabal, SP. 49p. }\end{array}$} \\
\hline
\end{tabular}

Table 2. Mean and variance analysis of Doppler echocardiographic parameters obtained in groups of dogs ( $\mathrm{n}=8$ ) affected by DMMV with CHF functional class Ib, in four different stages of evaluation, according to therapeutic protocols previously stipulated

\begin{tabular}{|c|c|c|c|c|c|c|c|c|c|c|c|}
\hline \multirow[t]{3}{*}{ Variable } & \multicolumn{10}{|c|}{ Doppler echocardiographic analysis } & \multirow[t]{3}{*}{ References } \\
\hline & \multicolumn{4}{|c|}{ G1 } & \multicolumn{4}{|c|}{ G2 } & \multicolumn{2}{|c|}{$P$} & \\
\hline & T0 & T14 & $\mathrm{T} 28$ & T56 & T0 & $\mathrm{T} 14$ & $\mathrm{~T} 28$ & T56 & Group & Time & \\
\hline RVDd & $0.36+/-0,19^{\mathrm{Aa}}$ & $0.42+/-0,17^{\mathrm{Aa}}$ & $0.51+/-0.17^{\mathrm{Aa}}$ & $0.44+/-0.14^{\mathrm{Aa}}$ & $0.41+/-0.19^{\text {Aa }}$ & $0.49+/-0.18^{\mathrm{Aa}}$ & $0.41+/-0.14^{\mathrm{Aa}}$ & $0.45+/-0.06^{\mathrm{Aa}}$ & 0.939 & 0.3 & $0.4-0.6$ \\
\hline IVSd & $0.67+/-0.15^{\mathrm{Aa}}$ & $0.68+/-0.12^{\mathrm{Aa}}$ & $0.64+/-0.15^{\mathrm{Aa}}$ & $0.69+/-0.12^{\mathrm{Aa}}$ & $0.69+/-0.17^{\text {Аа }}$ & $0.69+/-0.17^{\text {Aa }}$ & $0.65+/-0.18^{\mathrm{Aa}}$ & $0.69+/-0.14^{\mathrm{Aa}}$ & 0.644 & 0.559 & $0.4-0,6$ \\
\hline LVDd & $2.65+/-0.68^{\mathrm{Aa}}$ & $2.50+/-0.57^{\mathrm{Aa}}$ & $2.31+/-0.63^{\mathrm{Aa}}$ & $2.3+/-0.54^{\mathrm{Ba}}$ & $2.87+/-0.48^{\mathrm{Aa}}$ & $2.73+/-0.49^{\text {Aa }}$ & $2.69+/-0.49^{\mathrm{Aa}}$ & $2.62+/-0.64^{\mathrm{Ba}}$ & 0.255 & $0.03^{*}$ & $1.6-2.8$ \\
\hline PWLVd & $0.79+/-0.23^{\mathrm{Aa}}$ & $0.68+/-0.20^{\mathrm{Aa}}$ & $0.78+/-0.29^{\mathrm{Aa}}$ & $0.80+/-0.21^{\mathrm{Aa}}$ & $0.81+/-0.26^{\mathrm{Aa}}$ & $0.71+/-0.17^{\mathrm{Aa}}$ & $0.87+/-0.17^{\mathrm{Aa}}$ & $0.81+/-0.12^{\mathrm{Aa}}$ & 0.708 & 0.053 & $0.4-0.6$ \\
\hline IVSs & $1.03+/-0.24^{\mathrm{Aa}}$ & $0.98+/-0.14^{\mathrm{Aa}}$ & $0.99+/-0.17^{\mathrm{Aa}}$ & $0.98+/-0.11^{\mathrm{Aa}}$ & $0.98+/-0.20^{\mathrm{Aa}}$ & $0.90+/-0.10^{A a}$ & $0.93+/-0.13^{\mathrm{Aa}}$ & $0.88+/-0.17^{\mathrm{Aa}}$ & 0.324 & 0.467 & $0.6-1,0$ \\
\hline LVDs & $1.57+/-0.56^{\mathrm{Aa}}$ & $1.55+/-0.47^{\mathrm{Aa}}$ & $1.48+/-0.42^{\mathrm{Aa}}$ & $1.38+/-0.43^{\mathrm{Ba}}$ & $1.66+/-0.31^{\mathrm{Aa}}$ & $1.66+/-0.28^{\mathrm{Aa}}$ & $1.58+/-0.47^{\mathrm{Aa}}$ & $1.4+/-0.46^{\mathrm{Ba}}$ & 0.401 & $0.048^{*}$ & $0.8-1.6$ \\
\hline PWLVs & $1.08+/-0.36^{\mathrm{Aa}}$ & $1.10+/-0.36^{\mathrm{Aa}}$ & $1.16+/-0.32^{\mathrm{Aa}}$ & $1.04+/-0.16^{\mathrm{Aa}}$ & $1.1+/-0.27^{\mathrm{Aa}}$ & $1.15+/-0.26^{\mathrm{Aa}}$ & $1.14+/-0.21^{\mathrm{Aa}}$ & $1.28+/-0.33^{\mathrm{Aa}}$ & 0.558 & 0.826 & $0.6-1.0$ \\
\hline IVS\% & $62.5+/-21.57^{\mathrm{Aa}}$ & $36.5+/-14.81^{\mathrm{Aa}}$ & $51.63+/-19.09^{\mathrm{Aa}}$ & $46.38+/ 29.52^{\text {Aa }}$ & $46+/-21.31^{\mathrm{Aa}}$ & $33.63+/-26.3^{\text {Aa }}$ & $57.63+/-54.26^{\mathrm{Aa}}$ & $26.13+/-23.74^{\mathrm{Aa}}$ & 0436 & 0.230 & $34-73.2$ \\
\hline PWLV\% & $45.88+/-45.28^{A a}$ & $53.88+/-29.47^{\text {Аа }}$ & $38.13+/-35.52^{\text {Aa }}$ & $54.75+/-45.15^{\text {Аа }}$ & $47.75+/-33.7^{\mathrm{Aa}}$ & $59.38+/-22.58^{\text {Аа }}$ & $38.88+/-29.92^{\mathrm{Aa}}$ & $44.75+/-25.74^{\mathrm{Aa}}$ & 0.978 & 0.328 & $45.70-75.90$ \\
\hline $\mathrm{EF} \%$ & $76.5+/-8.40^{\mathrm{Aa}}$ & $69.75+/-7.97^{\mathrm{Aa}}$ & $73.88+/-10.45^{\text {Аa }}$ & $74.75+/-8.20^{\mathrm{Aa}}$ & $74.63+/-7.26^{\mathrm{Aa}}$ & $72.13+/-5.79^{A a}$ & $75.88+/-9.61^{\mathrm{Aa}}$ & $72.38+/-7.96^{\mathrm{Aa}}$ & 0.914 & 0.168 & $40-100$ \\
\hline FS\% & $43.75+/-7.55^{\mathrm{Aa}}$ & $39.13+/-8.23^{\mathrm{Ba}}$ & $39.38+/-5.75^{\mathrm{Ba}}$ & $42.38+/-6.42^{\mathrm{Aa}}$ & $41.38+/-5.01^{\mathrm{Aa}}$ & $38.75+/-4.2^{\mathrm{Ba}}$ & $39.8+/-3.56^{\mathrm{Ba}}$ & $39.75+/-4.23^{\mathrm{Ba}}$ & 0.591 & $0.02^{*}$ & $28-35$ \\
\hline Ao & $1.27+/-0.25^{\mathrm{Aa}}$ & $1.35+/-0.28^{\mathrm{Aa}}$ & $1.24+/-0.29^{\mathrm{Aa}}$ & $1.28+/-0.29^{\mathrm{Aa}}$ & $1.36+/-0.28^{\mathrm{Aa}}$ & $1.39+/-0.36^{\mathrm{Aa}}$ & $1.30+/-0.20^{\mathrm{Aa}}$ & $1.37+/-0.31^{\mathrm{Aa}}$ & 0.637 & 0.325 & $0.8-1.3$ \\
\hline LA & $1.9+/-0,47^{\mathrm{Aa}}$ & $1.99+/-0.46^{\mathrm{Aa}}$ & $2,04+/-0.58^{\mathrm{Aa}}$ & $2.04+/-0.48^{\mathrm{Aa}}$ & $2.41+/-0,55^{\mathrm{Aa}}$ & $2.44+/-0.32^{\mathrm{Aa}}$ & $2.23+/-0.44^{\mathrm{Aa}}$ & $2.16+/-0.39^{\mathrm{Aa}}$ & 0.175 & 0.435 & $0.8-1.8$ \\
\hline LA/Ao & $1.8+/-0.18^{\mathrm{Aa}}$ & $1.8+/-0.36^{\mathrm{Aa}}$ & $1.76+/-0.43^{\mathrm{Aa}}$ & $1.7+/-0.23^{\mathrm{Aa}}$ & $2.0+/-0.26^{\mathrm{Aa}}$ & $1.9+/-0.28^{\mathrm{Aa}}$ & $1.9+/-0.23^{\mathrm{Aa}}$ & $1.8+/-0.13^{\mathrm{Aa}}$ & 0.244 & 0.051 & 1.3 \\
\hline PEV & $0.69+/-0.06^{\mathrm{Aa}}$ & $0.69+/-0.10^{\mathrm{Aa}}$ & $0.68+/-0.06^{\mathrm{Aa}}$ & $0.70+/-0.05^{\mathrm{Aa}}$ & $0.75+/-0.25^{\text {Аа }}$ & $0.81+/-0.21^{\mathrm{Aa}}$ & $0.85+/-0.25^{\mathrm{Aa}}$ & $0.84+/-0.30^{\mathrm{Aa}}$ & 0.19 & 0.412 & 59-118 \\
\hline PAV & $0.57+/-0.11^{\mathrm{Aa}}$ & $0.45+/-0.11^{\mathrm{Aa}}$ & $0.47+/-0.10^{\mathrm{Aa}}$ & $0.46+/-0.10^{\mathrm{Aa}}$ & $0.43+/-0.11^{\mathrm{Aa}}$ & $0.71+/-0.20^{\mathrm{Aa}}$ & $0.67+/-0.26^{\mathrm{Aa}}$ & $0.57+/-0.19^{A a}$ & 0.125 & 0.795 & $33-93$ \\
\hline $\mathrm{E} / \mathrm{A}$ & $1.27+/-0.2^{\mathrm{Aa}}$ & $1.39+/-0.25^{\mathrm{Aa}}$ & $1.47+/-0.34^{\mathrm{Aa}}$ & $1.56+/-0.32^{\mathrm{Aa}}$ & $1.71+/-0.44^{\mathrm{Aa}}$ & $1.33+/-0.32^{\mathrm{Aa}}$ & $1.32+/-0.21^{\mathrm{Aa}}$ & $1.53+/-0.29^{\mathrm{Aa}}$ & 0. 125 & 0.173 & $1.04-2.42$ \\
\hline FVI & $0.09+/-0.01^{\mathrm{Aa}}$ & $0.08+/-0.02^{\mathrm{Aa}}$ & $009+/-0.01^{\mathrm{Aa}}$ & $0.07+/-0.01^{\mathrm{Aa}}$ & $0.086+/-0.03^{\mathrm{Aa}}$ & $0.11+/-0.04^{\mathrm{Aa}}$ & $0.11+/-0.06^{\mathrm{Aa}}$ & $0.11+/-0.04^{\mathrm{Aa}}$ & 0.696 & 0.221 & 0.094 \\
\hline VREG & $4.76+/-1.0^{\mathrm{Aa}}$ & $4.81+/-1.3^{\text {Аa }}$ & $4.55+/-1.1^{\mathrm{Aa}}$ & $4.54+/-1.12^{\mathrm{Aa}}$ & $4.99+/-1.3^{\mathrm{Aa}}$ & $4.74+/-1.0^{\mathrm{Aa}}$ & $4.57+/-0.9^{\mathrm{Aa}}$ & $4.6+/-1.1^{\mathrm{Aa}}$ & 0.191 & 0.059 & $4.7-5.9$ \\
\hline
\end{tabular}

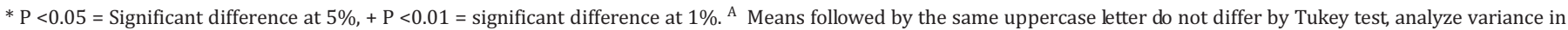
Time; ${ }^{a}$ means followed by same letter do not differ by Tukey test, variance analysis in the Group.

nificant changes were noticed in relation to baseline values. The radiographs were evaluated for parameters of the heart, using the method of VHS measurement, the heart chambers and pulmonary patterns. These conditions were necessary to identify the functional class of CHF, always seeking to identify the presence of tracheal collapse. Animals in both groups had a VHS of 10.8 vertebrae at the beginning of the assessment, indicating cardiectasia. After standard treatments, there was no significant reduction in these values although all reached the normal range (VHS $=10.5 \mathrm{v}$ ).

The evaluated electrocardiographic parameters showed no significant differences between them, with the prevalence of respiratory sinus arrhythmia as regular cardiac rhythm. We also observed the significant reduction in P-wave duration $\mathrm{ms}(\mathrm{p}<0.05)$ at the end of the clinical evaluation whereas the other variables were within normal values indicated for the species.

At the Doppler echocardiographic assessment, the animals of G1 and G2 showed no statistical differences between them although during the time of evaluation the animals of G1 had a significant reduction $(\mathrm{p}<0.05)$ in LVDd/s and FS\% only in moments T14 and T28, and non-significant in variable $\mathrm{EF} \%$ with the values of LA and the ratio LA/Ao remaining stable during the evaluation period. Though, animals of G2 showed high values in variables LVDd, PWLVd, LVDs, and PWLVs FS\% at the evaluation's beginning, and after therapy, there was significant reduction in variables LVDd/s, FS\% $(\mathrm{p}<0.05$ as well as in ventricular ejection fraction (EF\%) but not significantly. The size of LA and its relation LA/Ao were increased in the initial phase, with further non-significant reduction, but significant when compared to the animals of G1, which received furosemide in the treatment protocol (Table 2).

During the spectral Doppler mode significant changes in variables PEV, PAV, compared PEV / PAV, FVI and between G1 and G2 during the time of assessment were not observed, indicating the absence of ventricular diastolic dysfunction before and after the treatment protocol in groups; besides 
the maintenance of regurgitant velocity between 4.5 and $5.9 \mathrm{~m} / \mathrm{s}$.

\section{DISCUSSION}

The DMMV is a heart condition that affects small dog breeds, with its incidence increasing with age, reaching $75 \%$ of the canine population over the age of 12 years old (O'grady 1997, Buchaman 1997). The data found in the present scientific study showed the incidence of the disease in animals from 8 to 11 years old, correlating them with the development of the heart disease, as previously reported by Detweiler \& Patterson (1965), when they had demonstrated this correlation in dogs. In terms of size and breed, the study in screen was characterized by small animals, with a predisposition to the Poodle, Pinscher, Dachshund, Fox Terrier and mixed breed dogs, weighing from two to seven kilograms, confirming the findings of Thrusfield et al. (1985), Atkins (1995), O'Grady (1997) and Buchaman (1997).

For cardiac auscultation, the animals showed stable mitral murmur grade III or IV/VI, with results resembling those described by Kittleson (2006), with variations in the degree as the development of heart disease. In relation to the assessed clinical variables, the animals showed no clinical signs, characterized by functional class of patients studied. However, some animals were suffering from tracheal collapse leading to the appearance of reverse sneezing identified by owners as a mild cough, justifying also the concomitant development of tracheal collapse in animals with DMMV, the predisposition of this condition in chondrodytrophic breeds (Kittleson 1998, Sisson \& Kittleson 1999).

During the tests, the erythrogram in dogs representing $\mathrm{G} 1$, showed non-significant increase $\mathrm{Ht}, \mathrm{He}, \mathrm{Hb}$ and PT values after the use of furosemide, suggesting the occurrence of hemoconcentration, as described by Pereira (1996), due to the mentioned medicine be a potent loop diuretic (Jackson 1996). In contrast, dogs of $G 2$ showed no changes in red blood cell count. Serum levels of biochemical tests showed no significant change absent from deletery effects on liver and kidney functions, thus corroborating with what was described by Haggstron et al. (1996) and Atkins et al. (2002), studying the use of furosemide and enalapril maleate in dogs with DMMV. Serum sodium and potassium revealed a decline in the animals treated with furosemide, due to increased excretion caused by the medicine (Pereira 1996). Among animals that received enalapril maleate, it was shown no significant increase of serum potassium (Waltkins et al. 1976), probably due to the actions of SRAA, leading to decreased excretion of potassium, with the increase of these values in a benefic way, as reported by Ettinger et al. (1998), Maranhão et al. (1988) and Pereira et al. (2005).

A lack of variation in serum ACE between groups was verified, demonstrating the equality concerning the investigated functional class of CHF. However, in G2 a significant reduction during the time of evaluation was observed, indicating the effective action of enalapril maleate in the SRAA, leading to benefic reduction of post and cardiac preload (Katz 1994, Kitagawa et al. 1997, Lanzotti 2006). Though, in animals treated with furosemide the reduction was not significant in ACE values, even with the results showing a reduction in preload through the development of hemoconcentration.

In relation to the values of serum aldosterone concentration, the results showed again a similarity between the groups and after the implementation of the treatment protocol, there was a significant reduction in values of animals receiving enalapril maleate, justified by the pharmacological action in the SRAA (Watkins et al. 1976, Haggstrons et al. 1996, Tidholm et al. 2001). Furthermore, blood levels of aldosterone may increase with the clinical course of CHF so, in these cases, it might be used as a prognostic indicator for evolution and occurrence of sudden death in dogs with the studied heart disease (Ortega \& Gomes 2007, O'Sullivan et al. 2007).

In this test, the blood pressure values showed no significant variations between groups and neither during the assessment, excluding the development of hypotension in the studied therapeutic protocols. These data were also described by Pereira (1996), Kitagawa et al. (1997) and Pereira et al. (2005).

Nonetheless, at the radiographic evaluation, the animals of both groups showed a VHS of 10.8 vertebrae at the beginning of the assessment, indicating cardiectasia with further reduction to normal values (Buchaman \& Bucheler 1995) demonstrating the effectiveness of the method and treatments used, differing from the results obtained by Soares et al. (2004). At the echocardiography, both groups showed a decrease in P-wave duration at the end of clinical assessment, suggesting a reduction in left atrial enlargement (Tilley 1992, Wolf et al. 2000). We observed the prevalence of sinus arrhythmia breathing as cardiac rhythm due to involvement of the parasympathetic nervous system in these cases. This is a fact developed after blood pressure stabilization, also described by Miller \& Tilley (1995).

Doppler echocardiography is a complementary noninvasive method that determines the precise changes present in the given heart disease. After group G1 analysis, significant reductions during the evaluation time in the variables LVDd/ $s$ were verified, probably indicating a reduction in diastolic volume and end systolic ventricular. In DMMV, these values may be increased due to also increased preload, along with the presence of hyperkinesis of the left ventricular wall in response to positive inotropic stimulation and volume overload, thereby justifying the activation of the Frank Starling mechanism. This change has been observed once SF\% is increased (Boon 1998), with further non-significant reduction after the therapy was established (T56 days), due to reduced circulatory volume overload and hence the force of contraction of the myocardium. The variables LA and the ratio LA/Ao were initially increased due to atrial enlargement, with the animals in G1 showing non-significant reduction of the variables during the evaluation period (Firm \& Petri 2002, Kienle \& Thomaz 2004, Kittleson 2006, Borgarelli et al. 2007).

The animals of group G2 in the early evaluation showed an increase in the values of variables LVDd, PWLVd, LVDs and PWLVs, indicating the presence of left ventricular hypertrophy confirmed by increased myocardial FS\%, explained by the activation of the Frank Starling mechanism. After therapy, there was a significant decrease in the variables above and consequently decreased left ventricular ejection fraction 
(EF\%). These changes are explained by the reduction of preload and cardiac afterload, with improvement in ventricular efficiency. The size of the LA and the ratio LA / Ao increased in early stage, not significantly reduced after therapy with enalapril maleate are due to reduction in left atrial volume overload. The findings of the study confirmed the description given by Firm \& Petric (2002), Kienle \& Thomaz (2004) and Kittleson (2006), but differed from those presented by Deinert \& Ripken (2002). The data found in dogs from group G2 indicated the improvement of left ventricular function as also described in human patients (Maranhão et al. 1988, Mori et al. 2000) and veterinary patients (Biller et al. 1998). Moreover, the values of FS\% of animals carrying the studied valve CHF functional class Ib resembled values described by Kittleson (2006), when reported that these values may vary depending on the degree of valve commitment, with animals carrying mild to moderate $\mathrm{FS} \%$ presenting between 37 to $43 \%$.

Regarding the spectral Doppler mode, there were no significant changes in variables between groups and during the time of evaluation. However, no significant decline of mitral valve regurgitation rate was identified, but maintaining the values within the limits prescribed by Boon (1998) and Kienle \& Thomaz (2004). This reduction may suggest decreased intraventricular pressure overload and decrease in plasma volume, reflecting the decrease in diastolic and end systolic volume, and reduced FS\% in both groups evaluated of functional class Ib. This change may bring benefits to the patients with the studied valve disease, showing no side effects.

\section{CONCLUSIONS}

Under conditions in which the different stages were conducted, this test in dogs with DMMV CHF functional class $\mathrm{Ib}$, the later analysis, interpretation and discussion of the findings, one can conclude that:

Monotherapy based on enalapril maleate has a better efficiency in the control of the studied cardiovascular parameters;

Serum concentrations of ACE and aldosterone may be considered prognostic markers in the evolution of the CHF and to evaluate the therapeutic efficiency in dogs with the studied heart disease;

Doppler echocardiographic variables LVD, FS\%, LA and LA/Ao may be used as indicators for CHF prognosis and to evaluate the therapeutic efficiency.

Acknowledgments.- The Foundation for Development of UNESPFUNDUNESP, because of financial support for publishing this scientific article. But also to the Cardiology Service of the Veterinary Hospital Veterinary "Natel Governor Award" and the Faculty of Agricultural Sciences and Veterinary Medicine, UNESP/Campus Jaboticabal, yield per animal, the infrastructure and outpatient laboratories.

\section{REFERENCES}

Atkins C.E. 1995. Acquired valvular insufficiency, p.129-144. In: Miller M.S. \& Tilley L.P. (Eds), Manual of Canine and Feline Cardiology. $2^{\text {nd }}$ ed. W.B. Saunders, Philadelphia.

Atkins C.E., Brown W.A., Coats J.R., Crawford M.A., De Francesco T.C., Edwards J., Fox P.R., Keene B.W., Lehmkuhl L., Luethy M., Meurs K., Petrie J. P., Pipers F., Rosenthal S., Sidley J.A. \& Straus J. 2002. Effects of long-term administration of enalapril on clinical indications of renal function in dogs with compensated mitral regurgitation. Am. J. Vet. Med. Assoc. 21:654658.

Biller B., Horauf A. \& Kraft W. 1998. Treatment of mitral valve insufficiency in dogs with the ace inhibitor enalapril: A clinical progress study. Tierärztl. Prax. K, Kleintiere Heimtiere, 26:21-31.

Borgarelli M., Tarducci A., Zanatta R. \& Haggstrom J. 2007. Decreased systolic function and inadequate hypertrophy in large and small breed dogs with chronic mitral valve insufficiency. J. Vet. Med. Intern. 21:6167.

Boon J.A. 1998. Acquired heart disease, p.261-382. In: Ibid. (Ed.), Manual of Veterinary Echocardiography. Williams and Wilkins, Baltimore.

Buchaman J.W. 1997. Chronic valvular disease (endocardiose) in dogs. Sci. Med. Vet. Adv. Comp. 21:75-106.

Buchaman J.W. \& Bucheler J. 1995. Vertebral scale system to measure canine heart size in radiographs. J. Vet. Med. Intern. 206:194-199.

Calvert C.A. 1991. Effect of medical therapy on survival of patients with dilated cardiomyopathy. Vet. Clin. North. Am., Small. Anim. Pract. 21:919930.

Camacho A.A. 1996. Estudo clínico, caracterização morfométrica e quanti-tativa dos neurônios ganglionares atriais da faixa intercaval de cães com miocardiopatia dilatada congestiva idiopática. Tese de Livre-Docência em Clínica Médica de Pequenos Animais, Faculdade de Ciências Agrárias e Veterinárias, Universidade Estadual Paulista, Jaboticabal, SP. 56p.

Deinert M. \& Ripken A. 2002. A clinical trial about the efficacy of pimobendan in comparison to enalapril in dogs with mital valve endocardiosis. Part 2. Echocardiographic results. Available in www.vin.com/proceedings/ proceedings.plx/cid=WSAVA 2002. Accessed Oct. 23, 2007.

De Morais H.A. 2000. Pathophysiology of heart failure and evaluation of cardiac function, p.692-712. In: Ettinger S.J. \& Feldman E.C. (Eds), Textbook of Veterinary Internal Medicine. Vol.1. $5^{\text {th }}$ ed. W.B. Saunders, Philadelphia.

Detweiler D. \& Patterson D. 1965. The prevalence and types of cardiovascular disease in dogs. Annals of the New York Academy of Sciences, New York, USA, p.481-516.

Domenech 0., Bussadori C. \& Pradelli D. 2002. Echocardiographic prognostic indicators in mitral insufficiency patients. Available in www.vin.com/proceedings/proceedings.plx/cid=WSAVA 2002. Accessed Oct. 23, 2007.

Ettinger S.J., Benitz A.M., Ericsson G.F., Cifelli S., Jernigan A.D., Longhofer S.L., Trimboli W. \& Hanson P.D. 1998. Effects of enalapril maleate on survival of dogs with naturally acquired heart failure: The long-term investigations of veterinary enalapril (live) study group. Am. J. Vet. Med. Assoc. 213:1573-1577.

Firm I. \& Petric A. D. 2002. Epidemiological stufy o myxomatous valvular disease - A retrospective study of 195 cases. Available in www.vin.com/ proceedings/proceedings.plx/cid=WSAVA 2002. Accessed Oct. 23, 2007.

Haggstrons J., Harsson K., Karlberg B.E., Kvart C., Madej A. \& Olsson K. 1996. Effects of long-term treatment with enalapril on hidrolazine on the renninangiotensin-aldosterone system and fluid balance in dogs with naturally acquired mitral valve regurgitation. Am. J. Vet. Res. 57:1645-1652.

Jackson E.K. 1996. Diuréticos, p.502-22. In: Hardman J.G., Molinoff P.B. \& Goodman G.A. (Eds), As Bases Farmacológicas das Terapêuticas. 9a ed. McGraw-Hill, Mexico.

Jeresaty R.M. 1974. Mitral valve prolapsed click syndrome, p.203-232. In: Sonneblick E.H. \& Lesch M. (Eds), Valvular Heart Disease. Grune and Stratton, New York.

Katz A.M. 1994. The cardiomyopathy of overload: An unnatural growth response in the hypertrophied heart. Ann. Intern. Med. 121:363-371.

Keene B.W. \& Rush J.E. 1997. Terapia da insuficiência cardíaca, p.12191253. In: Ettinger S.J. \& Feldman E.C.J. (Eds), Tratado Medicina Interna Veterinária. Vol.2. 4⿳a ed. Manole, São Paulo.

Kienle R.D. \& Thomas W.P. 2004. Ecocardiografia, p.368-438. In: Nyland T.G. \& Mattoon J.S (Eds), Ultra-som Diagnóstico em Pequenos Animais. $2^{a}$ ed. Rocca, São Paulo. 
Kitagawa H., Wakamiya H., Kitoh K., Kuwahara Y., Ohba Y., Isaji M., Iwasaki T., Nakano M. \& Sasaki Y. 1997. Efficacy of monotherapy with benazepril, an angiotensin-converting enzyme inhibitor, in dogs with naturally acquired chronic mitral insufficiency. J. Vet. Med. Sci. 59:513-520.

Kittleson M.D. 1998. Mixomatous atrioventricular valvular degeneration, p.297-318. In: Kittleson M.D. \& Kienle R.D. (Eds), Small Animal Cardiovascular Medicine. Mosby Elsevier, St Louis.

Kittleson M.D. 2006. Myxomatous atrioventricular valvular degeneration. Textbook of Cardiovascular Medicine. $3^{\text {rd }}$ ed. and DVD. Mosby Elsevier, St Louis. 52p.

Knight D.H. 1992. Fisiopatologia da insuficiência cardíaca, p.944-969. Ettinger S.J. \& Feldman E.C.J. (Eds), Tratado Medicina Interna Veterinária. Vol.1. Manole, São Paulo.

Kogica M.M. 1999. Diuréticos, p.269-76. In: Spinosa M.M., Gorniak S.L. \& Bernardi M.M. (Eds), Farmacologia Aplicada a Medicina Veterinária. 2a ed. Guanabara, Rio de Janeiro.

Lanzotti M.E. 2006. Un nuevo desafio para los inhibidores de la ECA y para los antagonistas se los receptores de angiotensina II. La prevencion del desarrollo de fibrilacion auricular. Revta Argent. Cardiol. 35:144-149.

Maranhão M.F.C., Batlouni M., Albanesi F.M., Sbissa A.S. \& Martin A.M. 1988. Avaliação do maleato de enalapril na insuficiência cardíaca esquerda: estudo multicêntrico. Arq. Bras. Cardiol. 50:359-362.

Miller M.S. \& Tilley L.P. 1995. International Small Animal Cardiac Health Council: Recommendations for the diagnosis of heart disease and treatment of heart failure in small animals, p.473-485. In: Ibid. (Eds), Manual of Canine and Feline Cardiology. $2^{\text {nd }}$ ed. W.B. Saunders, Philadelphia.

Mori Y., Nakazawa M., Tominatsu H. \& Monima K. 2000. Long-term effect of angiotensin-converting enzyme inhibitor in volume overloaded heart during growth: Controlled pilot study. J. Am. Coll. Cardiol. 36:270-275.

Mucha C.J. 2007. Insuficiencia valvular mitral, p.261-273. In: Belerenian G. \& Mucha C.J. (Eds), Camacho A.A., Afecciones Cardiovasculares en Pequeños Animales. $2^{\underline{a}}$ ed. Inter-Medica, Buenos Aires.

O‘Grady M.R. 1997. Cardiomiopatia valvular adquirida, p.1316-1337. In: Ettinger S.J. \& Feldman E.C. (Eds), Tratado Medicina Interna Veterinária. Vol.2. 4aㅡ ed. Manole, São Paulo.

O‘Sullivan M.L., O‘Grady M.R. \& Minons S.L. 2007. Plasma big endothelin-I, atrial natriuretic peptide, aldosterone, and norepnephrine concentrations in normal Doberman pinchers and Doberman pinchers with dilatade cardiomyopathy. J. Vet. Intern. Med. 21:92-99.

Ortega M. \& Gomez L. 2007. Comparación en el manejo de pacientes con degeneración mixomatosa mitral con enalapril e con la combinación enalapril-espironolactona. Available in <www.cardiologiaveterinaria .com> Accessed Sept. 5, 2008.
Perdersen H.D. 2000. Diagnostico de la enfermedad de la valvula mixomatosa canina. Walthan Focus 10:3-9.

Pereira J.D.G. 1996. Variações de parâmetros clínico-laboratoriais de cães tratados com furosemida. Dissertação de Mestrado em Clínica Médica de Pequenos Animais, Faculdade de Ciências Agrárias e Veterinárias, Universidade Estadual Paulista, Jaboticabal, SP. 71p.

Pereira P.M., Camacho A.A. \& Morais H.A. 2005. Tratamento da insuficiência cardíaca com benazepril em cães com cardiomiopatia dilatada e endocardiose. Arq. Bras. Med. Vet. Zootec. 57:1-6.

Roth A.L. 1993. Use of angiotensin-converting-inhibitor in dog with congestive heart failure. Compend. Cont. Educ. 15:1240-1244.

Silva R.R. 2006. Determinação da atividade sérica da enzima conversora da angiotensina por método enzimático simplificado: valores de referência para cães sadios e avaliação em insuficientes renais crônicos. Tese de Doutorado em Clínica Médica de Pequenos Animais, Faculdade de Ciências Agrárias e Veterinárias, Universidade Estadual Paulista, Jaboticabal, SP. 59p.

Sisson D.D. \& Kittleson M.D. 1999. Management of heart failure: Principles of treatment, therapeutic, strategies and pharmacology, p.216-237. In: Fox P.R., Sisson D.V. \& Moise N.S. (Eds), Textbook of Canine and Feline Cardiology: Principles and clinical practice. $2^{\text {nd }}$ ed. W.B. Saunders, Philadelphia.

Snyder P.S. 1991. Canine hipertensive disease. Compend. Cont. Educ.13: 1785-1792.

Soares E.C., Larsson M.H.M.A. \& Pinto A.C.B.C.F. 2004. Aspectos radiográficos na doença valvular crônica. Ciência Rural 34:119-124.

Swenson L., Dagget W.N. \& Cooper T. 1996. Active contraction of the mitral valve: Intrinsic neuromuscular basis for valvular motion. Circulation 34:200-221.

Thrusfield M.V., Aitken C.G.G. \& Darker P.G.G. 1985. Observations on breed and sex in relation to canine heart valve incompetence. J. Small. Anim. Pract. 26:709-717.

Tidholm A., Haggstrons J. \& Hansson K. 2001. Efects of dilated cardiomyopathy on the rennin-angiotensin-aldosterone system, atrial peptide natriuretic activity, and thyroid hormone concentrations in dogs. Am. J. Vet. Res. 62: 961-967.

Tilley L.P. 1992. Essentials of Canine and Feline Electrocardiography. $3^{\text {rd }}$ ed. Lea and Febger, Philadelphia. 470p.

Watkins L.J., Bunton J.A., Haber E., Cant D.R. Smith F.W. \& Banger A.C. 1976. The renin-angiotensin-aldosterone system in congestive failure in conscious dogs. J. Clin. Invest. 57:1606-1617.

Wolf R., Camacho A.A. \& Souza R.C.A. 2000. Eletrocardiografia computadorizada em cães. Arq. Bras. Med. Vet. Zootec. 52:12-18. 